\title{
Serum microRNAs as non-invasive biomarkers for cancer
}

\author{
Jan C Brase*, Daniela Wuttig, Ruprecht Kuner, Holger Sültmann
}

\begin{abstract}
Human serum and other body fluids are rich resources for the identification of novel biomarkers, which can be measured in routine clinical diagnosis. microRNAs are small non-coding RNA molecules, which have an important function in regulating RNA stability and gene expression. The deregulation of microRNAs has been linked to cancer development and tumor progression. Recently, it has been reported that serum and other body fluids contain sufficiently stable microRNA signatures. Thus, the profiles of circulating microRNAs have been explored in a variety of studies aiming at the identification of novel non-invasive biomarkers.

In this review, we discuss recent findings indicating that circulating microRNAs are useful as non-invasive biomarkers for different tumor types. Additionally, we summarize the knowledge about the mechanism of microRNA release and the putative functional roles of circulating microRNAs. Although several challenges remain to be addressed, circulating microRNAs have the potential to be useful for the diagnosis and prognosis of cancer diseases.
\end{abstract}

\section{Background}

One of the major challenges in cancer research is the identification of stable biomarkers, which can be routinely measured in easily accessible samples. Over many decades it has been shown that cell-free DNA and RNA is present in serum and other body fluids and that these circulating nucleic acids may represent potential biomarkers (reviewed in [1-3]). One decade ago, microRNAs (miRNAs) were discovered as a novel class of evolutionarily conserved small (18 - 24 nucleotides) non-coding RNA molecules, which are important regulators of gene expression $[4,5]$. By targeting the 3' untranslated region (UTR) of mRNA transcripts, miRNAs influence RNA stability and translational efficiency via degradation or protein translation inhibition, respectively [4,6-9]. Thus, alterations in miRNA-expression can affect crucial biological processes in cancer development and progression, such as proliferation, differentiation and apoptosis $[10,11]$. For example, the well-described let 7 miRNA family is evolutionary conserved from $C$. elegans to humans and has been shown to directly target the human $R A S$ oncogenes [12]. In humans, significantly reduced expression of let-7 family

\footnotetext{
* Correspondence: j.brase@dkfz.de

Working Group Cancer Genome Research, German Cancer Research Center, Heidelberg, Germany
}

members has been found in various cancers including lung, colon, ovarian, and gastric cancer, as well as leiomyoma and melanoma [13]. Its decreased expression is associated with a significantly shorter survival of lung cancer patients and promotes the colony forming ability of lung cancer cells in vitro [14]. miRNA 221 and miRNA 222 are located on chromosome $\mathrm{X}$, and have been reported to be up regulated in various tumor types such as ovarian cancer [15], hepatocellular cancer [16] and glioblastomas [17]. Both miRNAs were shown to promote cell growth, cell cycle progression and invasion in these cancer types in vitro and in vivo [16,17]. Thus, they act as so-called "oncomirs". These effects are mediated by the direct inhibition of the tumor suppressors PTEN [18] and CDKN1B [15].

Similar to mRNA, the expression of miRNAs can be influenced by several factors, e.g. chromosomal rearrangements, promoter methylation changes and regulation of transcription, all of which are known to occur in human malignancies [19-22].

\section{Cell-free miRNAs and possible release mechanisms}

While miRNA presence is relevant for the regulation of cancer-associated genes in tissues, the possibility to extract and reliably determine cell-free miRNA content 
in body fluids like serum was first shown in 2008 [23]. This finding was confirmed by a subsequent study revealing that miRNAs are enriched in the small RNA fraction isolated from serum samples [24]. Cell-free miRNAs in body fluids are stable under harsh conditions including boiling, low/high $\mathrm{pH}$, extended storage and multiple freeze-thaw cycles [24-28]. In contrast, synthetic miRNAs were found to be quickly degraded by the high levels of RNAse activity in plasma [25]. Filtering and differential centrifugation experiments suggest that miRNAs are not derived from cells circulating in the blood [25]. At present, there are at least two possible explanations for the stability and origin of circulating miRNAs:

One hypothesis is that passive release occurs during tissue injury. For example, miRNA-208 was shown to be exclusively expressed in the heart and was measured in the serum after heart tissue injury [29]. The same unspecific release could also exist in cancer, since the high rate of proliferation and cell lysis in tumors might contribute to the abundance of miRNAs in the blood stream. Alternatively, miRNAs are contained in small particles and are therefore protected against RNase activity. Recently, it has been shown that a transfer of mRNA and miRNA between cells can be accomplished through microvesicles [30]. These are small (50 $\mathrm{nm}$ to $100 \mathrm{~nm}$ ) particles, which are shed from the cell plasma membrane into the extracellular space and released into the blood stream [31,32]. Microvesicles are derived from different cell types, e.g. reticulocytes, dendritic cells, $\mathrm{B} / \mathrm{T}$ cells and mast cells [33-37]. Additionally, it was shown that non-hematopoietic cells like intestinal epithelial cells and neuroglial cells are capable to release microvesicles [38,39].

\section{Putative functional roles of circulating miRNAs}

Microvesicles, also known as exosomes, are supposed to be important for cell-cell communication. However, the role of incorporated miRNA molecules is unclear. Hunter et al. compared the expression levels of miRNAs from microvesicles with that of platelets and peripheral blood mononuclear cells in healthy individuals [40]. Significant differences were found and target prediction demonstrated that the majority of the miRNAs from the microvesicles are involved in the regulation of hematopoiesis and cellular differentiation [40].

Recently, the mechanism of microvesicle based miRNA release was reported to involve a ceramidedependent secretory machinery [41]: Kosaka and colleagues showed that miRNA abundance changes after overexpression and inhibition of a rate-limiting enzyme involved in ceramide biosynthesis [41]. Interestingly, they also found that miRNAs are transported in microvesicles and exert gene silencing in recipient cells. The recent data suggest that cells can actively secrete endogenous miRNAs. However, it remains unclear whether there is a specific mechanism leading to an increase of certain selected miRNAs.

Although the exact mechanism for microvesicle formation and nucleic acid incorporation is still unknown, exosomes seem to have important roles in cell-cell communication [32]. Therefore, the contained miRNAs could also have important functions in tumor development and progression: In 1979, it was shown that tumor related exosomes are present in the blood of women suffering from ovarian cancer [42]. Recently, the quantity of tumor-derived exosomes in the peripheral circulation has been found to be highly correlated with ovarian cancer stages [26]. Moreover, the miRNA content of tumor cell-derived exosomes is correlated to the miRNA level in the primary tumor $[26,43]$. Skog et al. reported that glioblastoma-derived RNA contained in microvesicles is functional and is taken up by and processed in human brain microvascular endothelial cells (HBMVEC) in cultures [44]. This lead to the hypothesis that tumor cells use exosomes to transport genetic information, including miRNAs, to surrounding cells and thereby support tumor growth and progression [44]. If this hypothesis holds true, miRNAs could be suitable candidates to manipulate the microvesicles' target cells by regulating their RNA stability and translation. Moreover, circulating miRNAs might modulate immune responses [45,46]: For example, microvesicles derived from human melanoma and colon cancer can promote tumor growth and immune escape by mediating the differentiation of monocytes towards TGF $\beta$-secreting myeloid suppressive cells [45]. However, it has not been investigated if these effects are mediated by the miRNAs contained in the microvesicles.

\section{Circulating miRNAs reflect physiological and pathological changes}

In healthy individuals, the levels of cell-free miRNAs present in sera are stable [24,27]. Under healthy conditions, the serum miRNA profile is similar to that of circulating blood cells [24]. Thus, alterations of serum miRNA levels may be indicative of physiological or pathological changes and may possibly be used as surrogate biomarkers [47]. For example, circulating miRNAs were found in the sera of pregnant women [27]: miRNA-526a, miRNA-527 and miRNA-520d-5p showed a considerably high fold-change and could be used to distinguish pregnant from non-pregnant women with high accuracy. Moreover, placenta derived miRNAs (e.g. miRNA 141, miRNA 149, miRNA $2995 p$ and miRNA $517 a)$ are detectable in the maternal plasma, and their concentrations decrease directly after childbirth [48,49]. Therefore, miRNAs have been discussed as novel noninvasive markers for prenatal diagnosis [48]. 
As to pathological changes, tissue specific miRNAs were analyzed in the blood stream as markers for myocardial injury and drug induced liver injury: A rat model of acute myocardial infarction demonstrated that the plasma levels of the cardiac-specific miRNA-208 and $m i R N A-499$ are increased in this disease [50]. These miRNAs are also elevated in the plasma of human patients with acute myocardial infarction [50,51]. Drug induced liver injury, a frequent side effect which significantly influences the patient's health and treatment costs, is associated with increased plasma levels of miRNA 122 and miRNA 192 in a mouse model [52].

Cell-free miRNAs are also associated with inflammatory diseases [53,54]: Circulating miRNA-146a and $m i R N A-223$ were significantly reduced in septic patients when compared to patients with a systemic inflammatory response syndrome or healthy controls [53]. Furthermore, reduced plasma levels of miRNA 132 were observed in patients with rheumatoid arthritis and osteoarthrosis compared to healthy controls [55].

\section{Serum miRNAs as biomarkers for cancer diagnosis}

The availability of novel biomarkers could improve diagnosis and the clinical management of cancer. A perfect biomarker should be easily accessible in a noninvasive manner. Therefore, miRNA profiles in serum and plasma samples from cancer patients have been screened to identify novel biomarkers for the diagnosis of tumors (summarized in Table 1):

Lawrie et al. were the first to discover tumor specific deregulation of circulating miRNAs. Their study demonstrated that miRNA-21 is highly abundant in the sera of diffuse large B-cell lymphoma patients [23]. miRNA profiling of leukemia patients has shown circulating miRNA-92a to be considerably downregulated in the case of malignancy [56]. In 2008, Mitchell et al. reported that miRNAs derived from epithelial tumors are also rapidly released into the blood stream [25]. They used a mouse model to show that human miRNAs can be detected in the blood of mice after prostate cancer xenograft transplantation. The amount of human miRNAs was correlated with the xenograft tumor mass. These results clearly demonstrated that tumor-derived miRNAs can enter the circulation even when originating from epithelial cancers. Additionally, Mitchell et al. found circulating miRNA-141 to be significantly elevated in sera of metastatic prostate cancer when compared to those of healthy controls [25]. Ng and colleagues employed quantitative polymerase chain reaction (qPCR) to analyze miRNA profiles in colon cancer cells, the corresponding adjacent normal colonic tissue and plasma of patients and healthy controls $[57,58]$ : In this study, five miRNAs were found to be significantly overexpressed in the tumor cells as well as more abundant in the plasma samples of tumor patients compared to those of healthy volunteers (Table 1). miRNA-92 and $m i R N A-17-3 p$ were confirmed as diagnostic markers for colon cancer in an independent validation study [57]. Both miRNAs belong to the miRNA-17-92 gene cluster, which is supposed to be involved in cancer pathogenesis [59].

Circulating miRNAs were analyzed for the feasibility to detect early cancer development. Huang et al. studied the miRNA profiles in the blood stream of early stage colon cancer patients. Interestingly, they identified circulating miRNAs which distinguished adenomas from healthy controls with a $73 \%$ sensitivity and a $79 \%$ specificity [60]. These data indicate that cell-free miRNAs are promising markers for early tumor diagnosis. Novel biomarkers could be particularly useful for an earlier detection of tumors, which are clinically asymptomatic for extended periods. Pancreatic cancer, for instance, is often diagnosed in an advanced stage and associated with very short survival times. miRNA-21, miRNA-155, miRNA-196a and miRNA-210, which are known to be associated with pancreatic cancer, were also found to be elevated in the plasma of pancreatic carcinoma patients $[28,61]$. These miRNAs have been largely studied for their functional consequences: $m i R N A-21$ is known to be upregulated in several tumor entities and targets known tumor suppressive genes like PTEN and PDCD4 $[62,63]$. miRNA-155 has been found to downregulate the proapoptotic protein TP53INP1 [64]. miRNA-196a was described to be a prognostic marker in pancreatic cancer [65]. miRNA-210 is directly regulated by HIF1A and therefore induced by hypoxia [66].

The performance of circulating miRNAs as diagnostic markers has been compared to established blood-based markers: Women with high risk for ovarian cancer can undergo a CA 125 serum-based screening test. However, with a sensitivity of $40 \%$, CA- 125 is a poor marker for the early detection of this tumor. A set of serum miRNAs has recently been found to be highly abundant in patients with ovarian cancer. Some of these miRNAs were also deregulated in patients exhibiting normal CA-125 serum levels [67]. These data indicate that circulating miRNAs might be non-invasive markers, which could contribute to improving established clinical diagnostic tests.

Serum miRNA profiles among different cancer types have also been analyzed: Chen and colleagues compared the miRNA levels between colorectal and lung cancer patients [24]. Several miRNAs (e.g., $m i R-134, m i R-146 a$, $m i R-221, m i R-222, m i R-23 a)$ were significantly deregulated in the sera of both patient groups, suggesting that a miRNA profile common for several types of cancers may exist. On the other hand, tumor-specific miRNAs were also described: Lodes et al. analyzed the serum miRNA 
Table 1 Circulating miRNAs in the serum as diagnostic markers for different tumor entities

\begin{tabular}{|c|c|c|c|c|c|c|c|}
\hline $\begin{array}{l}\text { Tumor } \\
\text { entity }\end{array}$ & References & Study Design & Sample Size & $\begin{array}{l}\text { Circulating } \\
\text { miRNAs } \\
\text { examined }\end{array}$ & Technology & Normalization & Promising circulating miRNAs \\
\hline $\begin{array}{l}\text { B-Cell } \\
\text { Lymphoma }\end{array}$ & Lawrie et al. [23] & $\begin{array}{l}\text { Tumor vs. normal, } \\
\text { retrospective study } \\
\text { on prognosis }\end{array}$ & 60 patients vs. 43 healthy controls & 3 & $\begin{array}{l}\text { Quantitative } \\
\text { RT-PCR }\end{array}$ & miRNA-16 & $\begin{array}{l}\text { miRNA-155, miRNA-210, and } \\
\text { miRNA-21 }\end{array}$ \\
\hline \multirow[t]{2}{*}{$\begin{array}{l}\text { Breast } \\
\text { Cancer }\end{array}$} & Heneghan et al. [73] & Tumor vs. normal & 83 patients vs. 44 healthy controls & 7 & $\begin{array}{l}\text { Quantitative } \\
\text { RT-PCR }\end{array}$ & miRNA-16 & miRNA-195 and let7a \\
\hline & Zhu et al. [83] & Tumor vs. normal & 13 patients vs. 8 healthy controls & 3 & $\begin{array}{l}\text { Quantitative } \\
\text { RT-PCR }\end{array}$ & 18 s rRNA & miRNA-155 \\
\hline \multirow[t]{2}{*}{$\begin{array}{l}\text { Colon } \\
\text { Cancer }\end{array}$} & Huang et al. [60] & Tumor vs. normal & $\begin{array}{c}\text { Screening: } 20 \text { patients vs. } 20 \text { healthy controls } \\
\text { Validation: } 80 \text { patients, } 37 \text { adenomas and } 39 \\
\text { healthy controls }\end{array}$ & 12 & $\begin{array}{l}\text { Quantitative } \\
\text { RT-PCR }\end{array}$ & miRNA-16 & miRNA-29 and miRNA92a \\
\hline & Ng et al. [57] & $\begin{array}{l}\text { Tumor vs. normal, } \\
\text { tissue and serum }\end{array}$ & $\begin{array}{l}\text { Screening: } 5 \text { plasma samples, associated tumor/ } \\
\text { normal tissue 1.validation: } 25 \text { patients vs. } 20 \\
\text { healthy controls } \underline{\text {. validation } 180 \text { samples }}\end{array}$ & 95 & $\begin{array}{l}\text { Quantitative } \\
\text { RT-PCR Array }\end{array}$ & RNU6B & miR-17-3p and miR-92 \\
\hline $\begin{array}{l}\text { Gastric } \\
\text { Cancer }\end{array}$ & Tsujiura et al. [85] & Tumor vs. Normal & $\begin{array}{l}\text { Screening: } 8 \text { samples and associated tissue } \\
\text { Validation: } 69 \text { patients vs. } 30 \text { healthy controls }\end{array}$ & 5 & $\begin{array}{l}\text { Quantitative } \\
\text { RT-PCR }\end{array}$ & RNU6B & $\begin{array}{l}\text { miR-17-5p, miR-21, miR-106a, miR- } \\
106 b \text { and let-7a }\end{array}$ \\
\hline Leukemia & Tanaka et al. [56] & Tumor vs. Normal & $\begin{array}{l}\text { Screening: } 2 \text { patients vs. } 7 \text { healthy controls } \\
\text { Validation: } 61 \text { patients vs. } 16 \text { healthy controls }\end{array}$ & 723 & $\begin{array}{c}\text { microRNA } \\
\text { Microarray } \\
\text { (Agilent } \\
\text { Technologies) }\end{array}$ & miRNA-638 & miRNA-92a \\
\hline \multirow[t]{2}{*}{$\begin{array}{l}\text { Lung } \\
\text { Cancer }\end{array}$} & Chen et al. [24] & Tumor vs. normal & $\begin{array}{l}\text { Screening: Pool analysis Validation: } 152 \text { patients } \\
\text { vs. } 75 \text { healthy controls }\end{array}$ & $\begin{array}{l}\text { Genome-wide } \\
\text { profiling by } \\
\text { Solexa } \\
\text { sequencing }\end{array}$ & $\begin{array}{c}\text { Solexa } \\
\text { sequencing, } \\
\text { Quantitative } \\
\text { RT-PCR }\end{array}$ & $\begin{array}{l}\text { Directly normalized } \\
\text { to total RNA }\end{array}$ & miRNA-25 and miRNA-223 \\
\hline & Hu et al. [74] & $\begin{array}{l}\text { Study on prognosis } \\
\text { (Overall survival) }\end{array}$ & 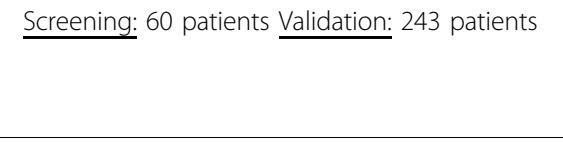 & $\begin{array}{l}\text { Genome-wide } \\
\text { profiling by } \\
\text { Solexa } \\
\text { sequencing }\end{array}$ & $\begin{array}{c}\text { Solexa } \\
\text { sequencing, } \\
\text { Quantitative } \\
\text { RT-PCR } \\
\end{array}$ & $\begin{array}{l}\text { Referenced to } \\
\text { control healthy } \\
\text { serum sample }\end{array}$ & $\begin{array}{l}\text { miR-486, miR-30d, miR-1 and } \\
\text { miR- } 499\end{array}$ \\
\hline $\begin{array}{l}\text { Oral } \\
\text { Cancer }\end{array}$ & Liu et al. [80] & Tumor vs. normal & 43 patients vs. 21 healthy controls & 1 & $\begin{array}{l}\text { Quantitative } \\
\text { RT-PCR arrays }\end{array}$ & miRNA-16 & $\operatorname{miR}-31$ \\
\hline $\begin{array}{l}\text { Ovarian } \\
\text { Cancer }\end{array}$ & Resnick et al. [67] & Tumor vs. normal & $\begin{array}{l}\text { Screening: } 9 \text { patients vs. } 4 \text { healthy controls } \\
\text { Validation: } 19 \text { patients vs. } 11 \text { healthy controls }\end{array}$ & 365 & $\begin{array}{l}\text { Quantitative } \\
\text { RT-PCR arrays }\end{array}$ & $\begin{array}{l}\text { U44/U48 and } \\
\text { miRNA-142-3p }\end{array}$ & $\begin{array}{l}\text { miRNA-21, miRNA-92, miRNA-93, } \\
\text { miRNA-126, miRNA-29a, miRNA- } \\
\text { 155, miRNA-127 and miRNA-99b }\end{array}$ \\
\hline \multirow[t]{2}{*}{$\begin{array}{l}\text { Pancreatic } \\
\text { Cancer }\end{array}$} & Ho et al. [28] & Tumor vs. normal & $\begin{array}{l}\text { Screening: } 11 \text { patients vs. } 14 \text { healthy controls, } \\
\text { Validation: } 11 \text { patients vs. } 11 \text { healthy controls }\end{array}$ & 1 & $\begin{array}{l}\text { Quantitative } \\
\text { RT-PCR arrays }\end{array}$ & $\begin{array}{l}\text { c. elegans spike-in } \\
\text { miRNA-54 }\end{array}$ & miRNA-210 \\
\hline & Wang et al. [61] & Tumor vs. normal & 49 patients vs. 36 healthy controls & 4 & $\begin{array}{l}\text { Quantitative } \\
\text { RT-PCR arrays }\end{array}$ & miRNA-16 & $\begin{array}{l}\text { miR-21, miR-210, miR-155, and } \\
\text { miR-196a }\end{array}$ \\
\hline \multirow[t]{2}{*}{$\begin{array}{l}\text { Prostate } \\
\text { Cancer }\end{array}$} & Mitchell et al. [25] & Tumor vs. normal & $\begin{array}{l}\text { Screening: Pool analysis Validation: } 25 \text { patients } \\
\text { vs. } 25 \text { healthy controls }\end{array}$ & 6 & $\begin{array}{l}\text { Quantitative } \\
\text { RT-PCR }\end{array}$ & $\begin{array}{l}\text { c. elegans spike-in } \\
\text { cel-miR-39, celmiR- } \\
54 \text {, and cel-miR-238 }\end{array}$ & miRNA-141 \\
\hline & Brase et al. [72] & $\begin{array}{l}\text { Low grade vs. high } \\
\text { grade }\end{array}$ & $\begin{array}{c}\text { Screening: } 7 \text { high grade vs. } 14 \text { low grade } \\
\text { Validation: } 116 \text { patients }\end{array}$ & 667 & $\begin{array}{l}\text { Quantitative } \\
\text { RT-PCR arrays }\end{array}$ & $\begin{array}{l}\text { c. elegans spike-in } \\
\text { cel-miR-39, celmiR- } \\
54 \text {, and cel-miR-238 }\end{array}$ & miRNA-141, miRNA-375 \\
\hline $\begin{array}{l}\text { Squamous } \\
\text { Cell } \\
\text { Carcinoma }\end{array}$ & Wong et al. [81] & $\begin{array}{l}\text { Tumor vs. Normal } \\
\text { tissue screening, } \\
\text { Validation in serum }\end{array}$ & 30 patients vs. 38 healthy controls & 1 & $\begin{array}{l}\text { Quantitative } \\
\text { RT-PCR arrays }\end{array}$ & MiRNA-16 & MiRNA-184 \\
\hline
\end{tabular}


profiles in five tumor entities (prostate, colon, ovarian, breast and lung cancer) using a high-density microarray. Here, different tumor entities could be distinguished based on the miRNA profiles in patients sera [68].

\section{Circulating miRNAs are correlated with tumor progression}

The findings discussed in the previous paragraph were based on comparisons of the miRNA serum levels between tumor patients and healthy controls. None of the described circulating miRNAs for the diagnosis of epithelial tumors showed correlations to histological subtypes, different stages or grades of cancer in further validation studies $[56,57,61,67]$. This suggests that the identified circulating miRNAs might be promising biomarkers for cancer detection but not necessarily appropriate for the prediction of the clinical courses of the diseases. In contrast, in tissue samples, miRNAs seem to be valuable markers to predict the clinical outcomes of cancer patients [69-71].

In our own study [72], we analyzed the miRNA profiles in sera of patients with highly aggressive compared to localized prostate cancer. Several circulating miRNAs were considerably higher abundant in patients with metastatic disease. Two independent validation studies indicated that miRNA-141 and miRNA-375 were the most promising markers correlated with prostate tumor progression. Recently, circulating miRNAs have also been reported to be correlated with clinicopathological variables (nodal and estrogen receptor status) in patients with breast cancer [73]. However, this study as well as our own data only demonstrated that circulating miRNAs are correlated with histopathological parameters, and not directly associated with patients' outcome. To evaluate the prognostic potential of the identified circulating miRNAs, larger retrospective validation studies integrating long-term follow-up data are required.

For lung cancer, it was shown that serum miRNAs are promising prognostic biomarkers: $\mathrm{Hu}$ et al. demonstrated that circulating miRNAs can be used to predict the clinical outcomes of non-small-cell lung cancer (NSCLC) patients [74]. In their screening study, the authors compared the serum miRNA profiles of patients with long and short survival times using Solexa sequencing and validated the abundance of 13 selected miRNAs in 243 patients by qPCR. Four miRNAs (miRNA-486, miRNA-30d, miRNA-1, and miRNA-499) were confirmed to be associated with patient outcome. miRNA-1 was already described to be significantly downregulated in lung cancer tissue, thereby leading to decreased cell proliferation, migration and motility. miRNA-1 is supposed to target the MET oncogene as well as the gene $H D A C 4$ [75]. Hu et al. also demonstrated that a combination of selected circulating miRNAs had a higher sensitivity than single biomarkers: Patients exhibiting large amounts of two or more high-risk miRNAs in the serum had a significantly increased probability of shorter survival times. Taken together, these results indicate a significant association of circulating miRNAs with the survival of NSCLC patients and therefore suggest that miRNAs are useful as prognostic markers.

\section{Technical advances and challenges to analyze circulating miRNA}

Due to the small amount of circulating miRNAs and the large amount of proteins, miRNA extraction from serum samples is technically challenging. To this end, several phenol/chloroform-based extraction protocols are available. Commercially available extraction kits without acid phase separation can also be used for the isolation of miRNA from body fluids.

Circulating miRNAs can be extracted from both serum as well as plasma samples. Serum has recently been described to yield lower amounts of circulating miRNAs compared to plasma [76]. In addition, the usefulness of serum samples has been questioned since the range of miRNAs from different samples can vary [76]. However, due to practical reasons, in the clinical routine, mainly serum samples are available. To this end, a good correlation was observed when the individual miRNA levels were compared between serum and plasma samples from the same patient donors [25]. Thus, both sample types seem to be suitable for the analysis of cell-free miRNAs.

One of the main problems associated with circulating miRNA extraction and comparison of sample collectives is the quantification of the miRNA. The low abundance of miRNA in serum can hardly be determined using spectrophotometers. A robust and sensitive method for the analysis of serum miRNAs is their relative quantification by a stem-loop reverse transcription PCR (RT-PCR), which has been widely used for the sensitive detection of low abundant circulating miRNAs [77] with high reproducibility. New technologies for serum-based miRNA analysis are emerging: For example, Lusi et al. designed a PCR- and label-free, sensitive detection method [78] based on an electrochemical sensor. After the hybrid formation of the miRNA with an inosine substitute, the oxidation of guanine generates an electrical signal, which can be quantified [78]. Microarray-based expression analysis is challenging since a large amount of RNA is needed for the analyses. Lodes et al. reported similar limits of detection for the analysis of circulating miRNAs for microarrays when compared to qPCRbased methods [68]. Deep sequencing technologies have resulted in a steep increase of the rate of newly described microRNAs [79]. Since 2007, almost all newly recovered microRNAs were derived from deep sequencing analyses. 
The current release (miRBase 16) encompasses over 15.000 microRNA gene loci. The user can search for tissue- and stage specific expression, and compare own data with microRNA profiles in different diseases. First studies indicate disease-specific fingerprints in serum [24,74]. Thus, large-scale miRNA sequencing appears to be very promising with respect to the identification of further biomarkers.

Due to the described technical and quality variations, the strategy of raw data normalization is a critical issue. Since endogenous ("housekeeping") controls do not exist, variances based on starting material and miRNA extraction have to be carefully balanced. So far, several normalization strategies for the analysis of circulating miRNAs are available (Table 1). Literature-based tissue housekeeping genes or miRNAs in the serum have been used for data normalization. For example, miRNA-16 was used as a reference for serum miRNA analysis in several studies $[23,60,61,73,80,81]$ (Table 1). This miRNA is consistently expressed in different human tissue entities [82] and is also detectable in serum samples. However, measurements of miRNA-16 in sera seem to be inconsistent. While some studies demonstrated a lack of significant differences between clinically defined entities [61,73], miRNA-16 was also found to be highly abundant in the sera of prostate cancer patients [68]. Small non-coding RNAs are also commonly used. However, these have been reported to show limitations due to degradation in the blood stream [23,60,83]. Mitchell and colleagues reported a spike-in normalization approach to control for technical variances during the purification process. Three C. elegans miRNAs (without sequence similarity to known human miRNAs) were included in the purification procedure and used for data normalization $[25,84]$.

The mentioned challenges concerning extraction, quantification and data processing steps in miRNA analysis may lead to considerably variable results and clearly demonstrate the need for better standardization methods.

\section{Future directions}

Circulating miRNAs offer great hope for the diagnosis and prognosis, and possibly prediction, of cancer. However, there are still limitations to the technology and the recent study designs. In-line with the lessons learned from gene expression profiling, clinical associations of miRNA presence identified in small sample cohorts have to be verified in larger and independent studies, and the efforts to translate the findings into clinical routine have to be increased. Initial data of miRNA in several tumor entities were either based on literature search or on a limited number of miRNAs (Table 1). Global screening studies monitoring a large set of human miRNAs are likely to lead to the discovery of better markers for specific diseases. In terms of biological or cellular functions, there is less known for any of the discovered serum miRNA. There are still controversial results concerning the relation of miRNA levels between tissue and corresponding serum: Several researchers suggested that tumor-associated miRNAs should be evaluated in the serum and in the tumor tissue $[25,57]$. This is conceptually in line with the role of microvesicles in neoplastic progression [44]. However, in lung cancer, the let-7 family was shown to be associated with clinical outcome in tissue samples only, and was not detected in the serum [74]. Thus, circulating miRNAs may not always be directly associated with the changes occurring in tumor tissues but may also reflect indirect effects. On the other hand, deregulated circulating miRNAs have been reported to be significantly reduced in post-operative states $[60,73,80,81,85]$.

Wang et al. concluded from their study that specific miRNAs are released into the blood stream after drug induced liver injury leading to a downregulation in the tissue [52]. In contrast to that, Tanaka et al. speculated that tumor cells rely on the specific intake of miRNAs from circulating microvesicles [56]. These contradictive assumptions clearly demonstrate a need for additional studies to elucidate the relation and function of tissue and serum miRNA expression levels. Furthermore, additional studies focusing on tumor specific microvesicles may provide insights into the biological roles of circulating miRNAs.

Finally, it is unknown how soon miRNA changes appear in the serum, although some first results showed that miRNAs occur early in the blood stream during colon cancer development [60] and after drug induced liver injury [52]. Serum miRNAs-122 and 192 are detectable prior to the routine detection of liver injury using an alanine aminotransferase enzyme test [52]. So far, no study has analyzed the influence of age, health conditions or dynamical changes of the serum miRNA profile in different individuals. Therefore, the kinetics of circulating miRNAs should be analyzed in detail to unravel if infection diseases or lifestyle changes can lead to changes in the serum and to correct for these changes in future studies. Additionally it is unknown, if medical treatment leads to a change of the serum miRNA profiles. In-vitro studies revealed that specific microRNAs impact on drug sensitivity [86]. Thus, it is possible that personal treatments are reflected by serum microRNA profiles. This aspect is highly relevant, since the individual treatment may influence the value of novel non-invasive miRNA biomarkers.

\section{Conclusions}

Although we are just beginning to understand the role and function of circulating miRNAs in the serum, 
miRNAs in body fluids are currently extensively explored for their potential as non-invasive diagnostic tumor markers. Tumor-specific circulating miRNAs may improve cancer diagnosis and prognosis, since several promising miRNAs have already been described as noninvasive biomarkers for different tumor entities. However, larger sample sets including long-term clinical data are urgently required for future studies. In contrast, circulating miRNAs for the prediction of drug responses have not been described so far. Isolation, quantification and normalization strategies have to be standardized before any of the novel miRNA biomarkers is applicable for clinical routine.

\section{Acknowledgements}

This work was supported by the German Federal Ministry for Education and Science in the framework of the Program for Medical Genome Research (01GS0890). The authors wish to apologize to the readers for the fact that - due to space restrictions - not all excellent studies on miRNA in serum of cancer patients could be mentioned.

\section{Authors' contributions}

JCB reviewed the literature, wrote and drafted the manuscript; RK, DW and HS corrected and finalized the manuscript. All authors read and approved the final version.

\section{Competing interests}

The authors declare that they have no competing interests.

Received: 14 July 2010 Accepted: 26 November 2010 Published: 26 November 2010

\section{References}

1. Swarup V, Rajeswari MR: Circulating (cell-free) nucleic acids-a promising, non-invasive tool for early detection of several human diseases. FEBS Lett 2007, 581:795-799

2. Fleischhacker M, Schmidt B: Circulating nucleic acids (CNAs) and cancer-a survey. Biochim Biophys Acta 2007, 1775:181-232.

3. Tsang JC, Lo YM: Circulating nucleic acids in plasma/serum. Pathology 2007, 39:197-207.

4. Bartel DP: MicroRNAs: genomics, biogenesis, mechanism, and function. Cell 2004, 116:281-297.

5. Ambros V: The functions of animal microRNAs. Nature 2004, 431:350-355

6. Bushati N, Cohen SM: microRNA functions. Annu Rev Cell Dev Biol 2007, 23:175-205.

7. Yekta $\mathrm{S}$, Shih $\mathrm{H}$, Bartel DP: MicroRNA-directed cleavage of HOXB8 mRNA. Science 2004, 304:594-596.

8. He L, Hannon GJ: MicroRNAs: small RNAs with a big role in gene regulation. Nat Rev Genet 2004, 5:522-531.

9. Ambros V: microRNAs: tiny regulators with great potential. Cell 2001, 107:823-826.

10. Miska EA: How microRNAs control cell division, differentiation and death. Curr Opin Genet Dev 2005, 15:563-568.

11. Esquela-Kerscher A, Slack FJ: Oncomirs - microRNAs with a role in cancer. Nat Rev Cancer 2006, 6:259-269.

12. Johnson SM, Grosshans H, Shingara J, Byrom M, Jarvis R, Cheng A Labourier E, Reinert KL, Brown D, Slack FJ: RAS is regulated by the let-7 microRNA family. Cell 2005, 120:635-647.

13. Peter ME: Let-7 and miR-200 microRNAs: guardians against pluripotency and cancer progression. Cell Cycle 2009, 8:843-852.

14. Takamizawa J, Konishi H, Yanagisawa K, Tomida S, Osada H, Endoh H, Harano T, Yatabe Y, Nagino M, Nimura Y, et al: Reduced expression of the let-7 microRNAs in human lung cancers in association with shortened postoperative survival. Cancer Res 2004, 64:3753-3756.
15. Wurz K, Garcia RL, Goff BA, Mitchell PS, Lee JH, Tewari M, Swisher EM: MiR221 and MiR-222 alterations in sporadic ovarian carcinoma: Relationship to CDKN1B, CDKNIC and overall survival. Genes Chromosomes Cancer 2010, 49:577-584.

16. Pineau P, Volinia S, McJunkin $K$, Marchio A, Battiston C, Terris B, Mazzaferro V, Lowe SW, Croce CM, Dejean A: miR-221 overexpression contributes to liver tumorigenesis. Proc Natl Acad Sci USA 2010, 107:264-269.

17. Zhang J, Han L, Ge Y, Zhou X, Zhang A, Zhang C, Zhong Y, You Y, Pu P, Kang C: miR-221/222 promote malignant progression of glioma through activation of the Akt pathway. Int J Oncol 2010, 36:913-920.

18. Chun-Zhi Z, Lei H, An-Ling Z, Yan-Chao F, Xiao Y, Guang-Xiu W, Zhi-Fan J, Pei-Yu P, Qing-Yu Z, Chun-Sheng K: MicroRNA-221 and microRNA-222 regulate gastric carcinoma cell proliferation and radioresistance by targeting PTEN. BMC Cancer 2010, 10:367.

19. Calin GA, Croce CM: MicroRNA signatures in human cancers. Nat Rev Cancer 2006, 6:857-866.

20. Rosenfeld N, Aharonov R, Meiri E, Rosenwald S, Spector Y, Zepeniuk M, Benjamin $\mathrm{H}$, Shabes $\mathrm{N}$, Tabak S, Levy A, et al: MicroRNAs accurately identify cancer tissue origin. Nat Biotechnol 2008, 26:462-469.

21. Chen CZ: MicroRNAs as oncogenes and tumor suppressors. N Engl I Med 2005, 353:1768-1771.

22. Caldas C, Brenton JD: Sizing up miRNAs as cancer genes. Nat Med 2005, 11:712-714.

23. Lawrie CH, Gal S, Dunlop HM, Pushkaran B, Liggins AP, Pulford K, Banham AH, Pezzella F, Boultwood J, Wainscoat JS, et al: Detection of elevated levels of tumour-associated microRNAs in serum of patients with diffuse large B-cell lymphoma. Br J Haematol 2008, 141:672-675.

24. Chen X, Ba Y, Ma L, Cai X, Yin Y, Wang K, Guo J, Zhang Y, Chen J, Guo X, et al: Characterization of microRNAs in serum: a novel class of biomarkers for diagnosis of cancer and other diseases. Cell Res 2008, 18:997-1006.

25. Mitchell PS, Parkin RK, Kroh EM, Fritz BR, Wyman SK, PogosovaAgadjanyan EL, Peterson A, Noteboom J, O'Briant KC, Allen A, et al: Circulating microRNAs as stable blood-based markers for cancer detection. Proc Natl Acad Sci USA 2008, 105:10513-10518.

26. Taylor DD, Gercel-Taylor C: MicroRNA signatures of tumor-derived exosomes as diagnostic biomarkers of ovarian cancer. Gynecol Oncol 2008, 110:13-21

27. Gilad $S$, Meiri E, Yogev $Y$, Benjamin $S$, Lebanony D, Yerushalmi $N$, Benjamin H, Kushnir M, Cholakh H, Melamed N, et al: Serum microRNAs are promising novel biomarkers. PLOS ONE 2008, 3:e3148.

28. Ho AS, Huang X, Cao H, Christman-Skieller C, Bennewith $\mathrm{K}$, Le QT, Koong AC: Circulating miR-210 as a Novel Hypoxia Marker in Pancreatic Cancer. Transl Oncol 2010, 3:109-113.

29. Ji X, Takahashi R, Hiura Y, Hirokawa G, Fukushima Y, Iwai N: Plasma miR208 as a biomarker of myocardial injury. Clin Chem 2009, 55:1944-1949.

30. Valadi H, Ekstrom K, Bossios A, Sjostrand M, Lee JJ, Lotvall JO: Exosomemediated transfer of mRNAs and microRNAs is a novel mechanism of genetic exchange between cells. Nat Cell Biol 2007, 9:654-659.

31. Caby MP, Lankar D, Vincendeau-Scherrer C, Raposo G, Bonnerot C Exosomal-like vesicles are present in human blood plasma. Int Immunol 2005, 17:879-887.

32. van Niel G, Porto-Carreiro I, Simoes S, Raposo G: Exosomes: a common pathway for a specialized function. J Biochem 2006, 140:13-21.

33. Escola JM, Kleijmeer MJ, Stoorvogel W, Griffith JM, Yoshie O, Geuze HJ: Selective enrichment of tetraspan proteins on the internal vesicles of multivesicular endosomes and on exosomes secreted by human Blymphocytes. J Biol Chem 1998, 273:20121-20127.

34. Andre F, Schartz NE, Movassagh M, Flament C, Pautier P, Morice P, Pomel C, Lhomme C, Escudier B, Le Chevalier T, et al: Malignant effusions and immunogenic tumour-derived exosomes. Lancet 2002, 360:295-305.

35. Valenti R, Huber V, Filipazzi P, Pilla L, Sovena G, Villa A, Corbelli A, Fais S, Parmiani G, Rivoltini L: Human tumor-released microvesicles promote the differentiation of myeloid cells with transforming growth factor-betamediated suppressive activity on T lymphocytes. Cancer Res 2006 66:9290-9298.

36. Thery C, Regnault A, Garin J, Wolfers J, Zitvogel L, Ricciardi-Castagnoli P, Raposo G, Amigorena S: Molecular characterization of dendritic 
cell-derived exosomes. Selective accumulation of the heat shock protein hsc73. J Cell Biol 1999, 147:599-610.

37. Raposo G, Nijman HW, Stoorvogel W, Liejendekker R, Harding CV, Melief CJ, Geuze HJ: B lymphocytes secrete antigen-presenting vesicles. J Exp Med 1996, 183:1161-1172.

38. Fevrier B, Vilette D, Archer F, Loew D, Faigle W, Vidal M, Laude H, Raposo G: Cells release prions in association with exosomes. Proc Natl Acad Sci USA 2004, 101:9683-9688

39. van Niel G, Raposo G, Candalh C, Boussac M, Hershberg R, CerfBensussan N, Heyman M: Intestinal epithelial cells secrete exosome-like vesicles. Gastroenterology 2001, 121:337-349.

40. Hunter MP, Ismail N, Zhang X, Aguda BD, Lee EJ, Yu L, Xiao T, Schafer J, Lee ML, Schmittgen TD, et al: Detection of microRNA expression in human peripheral blood microvesicles. PLOS ONE 2008, 3:e3694.

41. Kosaka N, Iguchi H, Yoshioka Y, Takeshita F, Matsuki Y, Ochiya T: Secretory Mechanisms and Intercellular Transfer of MicroRNAs in Living Cells. J Biol Chem 2010, 285:17442-17452.

42. Taylor DD, Doellgast GJ: Quantitation of peroxidase-antibody binding to membrane fragments using column chromatography. Anal Biochem 1979, 98:53-59.

43. Rabinowits G, Gercel-Taylor C, Day JM, Taylor DD, Kloecker GH: Exosomal microRNA: a diagnostic marker for lung cancer. Clin Lung Cancer 2009, 10:42-46.

44. Skog J, Wurdinger T, van Rijn S, Meijer DH, Gainche L, Sena-Esteves M, Curry WT Jr, Carter BS, Krichevsky AM, Breakefield XO: Glioblastoma microvesicles transport RNA and proteins that promote tumour growth and provide diagnostic biomarkers. Nat Cell Biol 2008, 10:1470-1476.

45. Valenti R, Huber V, lero M, Filipazzi P, Parmiani G, Rivoltini L: Tumorreleased microvesicles as vehicles of immunosuppression. Cancer Res 2007, 67:2912-2915.

46. Baj-Krzyworzeka M, Szatanek R, Weglarczyk K, Baran J, Zembala M: Tumourderived microvesicles modulate biological activity of human monocytes. Immunol Lett 2007, 113:76-82.

47. Cortez MA, Calin GA: MicroRNA identification in plasma and serum: a new tool to diagnose and monitor diseases. Expert Opin Biol Ther 2009, 9:703-711.

48. Chim SS, Shing TK, Hung EC, Leung TY, Lau TK, Chiu RW, Lo YM: Detection and characterization of placental microRNAs in maternal plasma. Clin Chem 2008, 54:482-490.

49. Luo SS, Ishibashi O, Ishikawa G, Ishikawa T, Katayama A, Mishima T, Takizawa T, Shigihara T, Goto T, Izumi A, et al: Human villous trophoblasts express and secrete placenta-specific microRNAs into maternal circulation via exosomes. Biol Reprod 2009, 81:717-729.

50. Wang GK, Zhu JQ, Zhang JT, Li Q, Li Y, He J, Qin YW, Jing Q: Circulating microRNA: a novel potential biomarker for early diagnosis of acute myocardial infarction in humans. Eur Heart J 2010, 31:659-666.

51. Adachi T, Nakanishi M, Otsuka Y, Nishimura K, Hirokawa G, Goto Y, Nonogi $\mathrm{H}$, Iwai N: Plasma MicroRNA 499 as a Biomarker of Acute Myocardial Infarction. Clin Chem 2010, 56:1183-1185.

52. Wang K, Zhang S, Marzolf B, Troisch P, Brightman A, Hu Z, Hood LE, Galas DJ: Circulating microRNAs, potential biomarkers for drug-induced liver injury. Proc Natl Acad Sci USA 2009, 106:4402-4407.

53. Wang JF, Yu ML, Yu G, Bian JJ, Deng XM, Wan XJ, Zhu KM: Serum miR$146 a$ and miR-223 as potential new biomarkers for sepsis. Biochem Biophys Res Commun 2010, 394:184-188.

54. Vasilescu C, Rossi S, Shimizu M, Tudor S, Veronese A, Ferracin M, Nicoloso MS, Barbarotto E, Popa M, Stanciulea O, et al: MicroRNA fingerprints identify miR-150 as a plasma prognostic marker in patients with sepsis. PloS One 2009, 4:e7405.

55. Murata K, Yoshitomi H, Tanida S, Ishikawa M, Nishitani K, Ito H, Nakamura T: Plasma and synovial fluid microRNAs as potential biomarkers of rheumatoid arthritis and osteoarthritis. Arthritis Res Ther 2010, 12:R86.

56. Tanaka M, Oikawa K, Takanashi M, Kudo M, Ohyashiki J, Ohyashiki K, Kuroda M: Down-regulation of miR-92 in human plasma is a novel marker for acute leukemia patients. PLOS ONE 2009, 4:e5532.

57. Ng EK, Chong WW, Jin H, Lam EK, Shin VY, Yu J, Poon TC, Ng SS, Sung JJ: Differential expression of microRNAs in plasma of patients with colorectal cancer: a potential marker for colorectal cancer screening. Gut 2009, 58:1375-1381.
58. Schetter AJ, Harris CC: Plasma microRNAs: a potential biomarker for colorectal cancer? Gut 2009, 58:1318-1319.

59. He L, Thomson JM, Hemann MT, Hernando-Monge E, Mu D, Goodson S, Powers S, Cordon-Cardo C, Lowe SW, Hannon GJ, Hammond SM: A microRNA polycistron as a potential human oncogene. Nature 2005, 435:828-833.

60. Huang Z, Huang D, Ni S, Peng Z, Sheng W, Du X: Plasma microRNAs are promising novel biomarkers for early detection of colorectal cancer. Int J Cancer 2010, 127:118-126.

61. Wang J, Chen J, Chang P, LeBlanc A, Li D, Abbruzzesse JL, Frazier ML, Killary AM, Sen S: MicroRNAs in plasma of pancreatic ductal adenocarcinoma patients as novel blood-based biomarkers of disease. Cancer Prev Res (Phila Pa) 2009, 2:807-813.

62. Frankel LB, Christoffersen NR, Jacobsen A, Lindow M, Krogh A, Lund AH: Programmed cell death 4 (PDCD4) is an important functional target of the microRNA miR-21 in breast cancer cells. J Biol Chem 2008, 283:1026-1033.

63. Lou $Y$, Yang $X$, Wang $F$, Cui $Z$, Huang $Y$ : MicroRNA-21 promotes the cell proliferation, invasion and migration abilities in ovarian epithelial carcinomas through inhibiting the expression of PTEN protein. Int I Mol Med 2010, 26:819-827.

64. Gironella M, Seux M, Xie MJ, Cano C, Tomasini R, Gommeaux J, Garcia S, Nowak J, Yeung ML, Jeang KT, et al: Tumor protein 53-induced nuclear protein 1 expression is repressed by miR-155, and its restoration inhibits pancreatic tumor development. Proc Natl Acad Sci USA 2007, 104:16170-16175.

65. Szafranska AE, Davison TS, John J, Cannon T, Sipos B, Maghnouj A, Labourier $E$, Hahn SA: MicroRNA expression alterations are linked to tumorigenesis and non-neoplastic processes in pancreatic ductal adenocarcinoma. Oncogene 2007, 26:4442-4452.

66. Crosby ME, Kulshreshtha R, Ivan M, Glazer PM: MicroRNA regulation of DNA repair gene expression in hypoxic stress. Cancer Res 2009, 69:1221-1229.

67. Resnick KE, Alder H, Hagan JP, Richardson DL, Croce CM, Cohn DE: The detection of differentially expressed microRNAs from the serum of ovarian cancer patients using a novel real-time PCR platform. Gynecol Oncol 2009, 112:55-59.

68. Lodes MJ, Caraballo M, Suciu D, Munro S, Kumar A, Anderson B: Detection of cancer with serum miRNAs on an oligonucleotide microarray. PLOS One 2009, 4:e6229.

69. Yu SL, Chen HY, Chang GC, Chen CY, Chen HW, Singh S, Cheng CL, Yu CJ, Lee $Y C$, Chen $H S$, et al: MicroRNA signature predicts survival and relapse in lung cancer. Cancer Cell 2008, 13:48-57.

70. Schetter AJ, Leung SY, Sohn JJ, Zanetti KA, Bowman ED, Yanaihara N, Yuen ST, Chan TL, Kwong DL, Au GK, et al: MicroRNA expression profiles associated with prognosis and therapeutic outcome in colon adenocarcinoma. JAMA 2008, 299:425-436.

71. Calin GA, Ferracin M, Cimmino A, Di Leva G, Shimizu M, Wojcik SE, lorio MV Visone $\mathrm{R}$, Sever NI, Fabbri M, et al: A MicroRNA signature associated with prognosis and progression in chronic lymphocytic leukemia. $N$ Engl J Med 2005, 353:1793-1801.

72. Brase JC, Johannes M, Schlomm T, Falth M, Haese A, Steuber T, Beissbarth T, Kuner R, Sultmann H: Circulating miRNAs are correlated with tumor progression in prostate cancer. Int I Cancer 2010, Epub.

73. Heneghan HM, Miller N, Lowery AJ, Sweeney KJ, Newell J, Kerin MJ: Circulating microRNAs as novel minimally invasive biomarkers for breast cancer. Ann Surg 2010, 251:499-505.

74. Hu Z, Chen X, Zhao Y, Tian T, Jin G, Shu Y, Chen Y, Xu L, Zen K, Zhang C, Shen $\mathrm{H}$ : Serum microRNA signatures identified in a genome-wide serum microRNA expression profiling predict survival of non-small-cell lung cancer. J Clin Oncol 2010, 28:1721-1726.

75. Nasser MW, Datta J, Nuovo G, Kutay H, Motiwala T, Majumder S, Wang B, Suster S, Jacob ST, Ghoshal K: Down-regulation of micro-RNA-1 (miR-1) in lung cancer. Suppression of tumorigenic property of lung cancer cells and their sensitization to doxorubicin-induced apoptosis by miR-1. J Biol Chem 2008, 283:33394-33405.

76. Heneghan HM, Miller N, Kerin MJ: Circulating miRNA Signatures: Promising Prognostic Tools for Cancer. J Clin Oncol 2010, 28:e573-574. 
77. Chen C, Ridzon DA, Broomer AJ, Zhou Z, Lee DH, Nguyen JT, Barbisin M, Xu NL, Mahuvakar VR, Andersen MR, et al: Real-time quantification of microRNAs by stem-loop RT-PCR. Nucleic Acids Res 2005, 33:e179.

78. Lusi EA, Passamano M, Guarascio P, Scarpa A, Schiavo L: Innovative electrochemical approach for an early detection of microRNAs. Anal Chem 2009, 81:2819-2822.

79. Kozomara A, Griffiths-Jones S: miRBase: integrating microRNA annotation and deep-sequencing data. Nucleic Acids Res 2010, Epub.

80. Liu CJ, Kao SY, Tu HF, Tsai MM, Chang KW, Lin SC: Increase of microRNA miR-31 level in plasma could be a potential marker of oral cancer. Oral Dis 2010, 16:360-364.

81. Wong TS, Liu XB, Wong BY, Ng RW, Yuen AP, Wei WI: Mature miR-184 as Potential Oncogenic microRNA of Squamous Cell Carcinoma of Tongue. Clin Cancer Res 2008, 14:2588-2592.

82. Liang $Y$, Ridzon D, Wong $L$, Chen $C$ : Characterization of microRNA expression profiles in normal human tissues. BMC Genomics 2007, 8:166.

83. Zhu W, Qin W, Atasoy U, Sauter ER: Circulating microRNAs in breast cancer and healthy subjects. BMC Res Notes 2009, 2:89.

84. Kroh EM, Parkin RK, Mitchell PS, Tewari M: Analysis of circulating microRNA biomarkers in plasma and serum using quantitative reverse transcription-PCR (qRT-PCR). Methods 2010, 50:298-301.

85. Tsujiura M, Ichikawa D, Komatsu S, Shiozaki A, Takeshita H, Kosuga T, Konishi H, Morimura R, Deguchi K, Fujiwara H, et al: Circulating microRNAs in plasma of patients with gastric cancers. Br I Cancer 2010, 102:1174-1179.

86. Rao X, Di Leva G, Li M, Fang F, Devlin C, Hartman-Frey C, Burow ME, Ivan M, Croce CM, Nephew KP: MicroRNA-221/222 confers breast cancer fulvestrant resistance by regulating multiple signaling pathways. Oncogene 2010, Epub.

doi:10.1186/1476-4598-9-306

Cite this article as: Brase et al: Serum microRNAs as non-invasive biomarkers for cancer. Molecular Cancer 2010 9:306.

\section{Submit your next manuscript to BioMed Central and take full advantage of:}

- Convenient online submission

- Thorough peer review

- No space constraints or color figure charges

- Immediate publication on acceptance

- Inclusion in PubMed, CAS, Scopus and Google Scholar

- Research which is freely available for redistribution

Submit your manuscript at www.biomedcentral.com/submit
Ciomed Central 